DOI: 10.22616/REEP.2020.036

\title{
The Pedagogical Aspects of Reducing Adolescent Violence in the School Environment
}

\author{
Ilona Ledina ${ }^{1}$ Mg.paed.; Iveta Lice-Zikmane ${ }^{2}$ Dr.paed. \\ Jurmala City Orphan's Court ${ }^{1}$; Latvia University of Life Science and Technologies ${ }^{2}$, Latvia \\ ilona.ledina@inbox.lv1; iveta.lice@1lu.lv²
}

\begin{abstract}
School violence against adolescents is a pressing problem in today's society, which not only restricts a pupil's right to a safe and violence-free environment, but also has adverse consequences for the individual and for society a whole. The physiological and psychological changes characteristic of adolescence lead to inconsistent and incomprehensible behaviour in adolescents. Adolescents have a desire to be noticed, to prove to themselves and others that they have personalities. In the event that adolescents fail to assert themselves in a generally accepted way, they will self-assert themselves with aggressive behaviour. The aim of the study is to find out the views of adolescents about reducing violence in the school environment. The research methods such as questionnaires, discussions and experiment were used in the current investigation. The place of the research: Jurmala, Latvia. Altogether 51 respondents take part in this investigation. The study results demonstrated different results before and after approbation the methodological material "Be positive!". Adolescents' sense of security at school and in the classroom has improved. Adolescents' sense of fear from their classmates has significantly decreased ('often' decreased by $15.18 \%$; 'rarely' increased by $9 \%$ ).
\end{abstract}

Keywords: adolescent, reduction of violence, school environment, school education.

\section{Introduction}

Adolescents are one of the most sensitive groups in society. During this period of development, they are confronted not only with physiological changes in the body but also with the self-realization and identity.

The school environment encompasses both the physical environment, including safety and security, and the psychological environment, including the school climate, classroom management and discipline, and the relationship between teachers and students and between students. School-related violence in all its forms, including bullying, is an infringement of children's and adolescents' rights to education and health and wellbeing. No country can achieve inclusive and equitable quality education for all if learners experience violence in school (Behind the numbers..., 2019). Violence takes many forms around the world. The causes of violence are also deeply rooted in culture, social environment and economic structures.

During the teenage the polarity of the mind dominates: purposefulness - perseverance, increased selfesteem-lack of self-esteem, aggression - shyness, tenderness - cruelty, romanticism - cynicism. This age is a platform for the development of motives and values, beliefs, the ability to respond appropriately to comments and true and false criticism (Marchenkova, 2017). Scientist N.J. Cobb (2010) points out:

- the biological development of adolescents, characterized puberty and sexual maturation;

- psychological development of adolescents, oriented towards the recognition of the individual's identity;

- social development with the strengthening of appropriate social status.

Psychologist H.M. Knoff (Knoff, 2003), who focuses on pupil and school management, believes, that the main characteristic of adolescence is their tendency to integrate into adult life, but they are not able to do it physically and psychologically. They strive to claim the same rights as adults in the style of dress, a behaviour that is often provocative. Teenagers express their behaviour by smoking, using alcohol, slurs, and having sexual relationships. Adolescents experience difficult experiences related to new relationships with their peers and parents. They learn to analyse their personality traits and behaviours.

The World Health Organization defines violence as -the intentional use of physical force or power, threatened or actual, against oneself, another person, or against a group or community, that either results in or has a high likelihood of resulting in injury, death, psychological harm, maldevelopment or deprivation (World report on violence..., 2002, 4). The forms of violence:

- -self-directed violence (man is harming himself). Self-directed violence includes suicidal 
behaviour and self-abuse such as self-mutilation.

- -interpersonal violence (directed against another person);

- $\quad$-collective violence (violent conflicts between nations and groups, state and group terrorism).

The typology also captures the nature of violent acts, which can be physical, sexual or psychological or involve deprivation or neglect.

Aggression is motivated destructive activity that is contrary to the norms of society. Aggression results in physical or psycho-emotional harm. It can be directed externally-towards a person to cause significant harm to it - and it can be directed externally and internally - towards itself. Aggression can be used as a means to accomplish some goals, as an anti-aggression, and also as a target to attack, hurt and destroy under the influence of anger (Mendes et al., 2008). Adolescents are active users of verbal aggression. This is also largely due to the specific nature of the age group. Verbal aggression is not always blatant adolescent aggression towards others. Teenagers use harsh words to draw attention from parents and others, to test their parents love, to imitate their idols.

The consequences of aggression always affect more than just the aggressor himself. On the one hand, aggression is related to the excitement of the individual, on the other hand, there are other individuals who are directly or indirectly affected by the consequences of that aggressor's excitement. Aggression as a behavioural model is based on social influences, both congenital factors and negative childhood experiences. In childhood it has been explained to the child that aggression is unacceptable behaviour, but during the lifetime the individual faces conflicting situations. Teenagers who are victims of violence are characterized by physical aggression, which serves to gain and affirm their social status, and it takes a long time to change such behaviour (Poudžiunas, 2011).

One of the causes of adolescent behaviour problems is family instability. Priority focuses on adolescent behavioural problems, but the issue of family remains a secondary concern (Medne, 2010). A characteristic feature of adolescence is the tendency to be independent from parents, but at the same tome the teenager needs the love and support of this parents. J.R. Correll (Correll, Walker, Edwards, 2017) emphasizes that violent behaviour by adolescents not only affects their peers in the school environment but also their parents negatively affects family relationships. The family creates a complex emotional background. In this case, family support and understanding does not give the teenager a sense of security. The relationships between the parents of the teenager, the emotional climate in the family and the cooperation between all members of the family create the conditions for the teenagers psychological and social development. To a large extent, the personality traits and flexibility of parents are decisive in understanding their behaviour. Scientist H.M. Knoff has pointed out two less favourable forms of parent-generational relationship (Knoff, 2003):

- cruel, despotic control of the teenager and authoritarian parenting style;

- complete lack of control when a teenager is left behind.

Attachment behaviour is explained as behaviour that is biologically rooted and is part of human nature and is activated when the child is not feeling well or feeling bad (Simane-Vigante, Plotka, Blumenau, 2018). On the other hand, children who are frequently bullied are more likely to feel like an outsider at school. Educational outcomes are also lower (Behind the numbers..., 2019).

In a school environment adolescent accumulate beliefs and behaviours that are accepted in society and in the family. In practice, the authors are quite often confronted with cases where educational institutions, family physicians report problems in the family but do not inform law enforcement, or inform in cases where the problem is aggravated, or worse, find the consequences.

In the Global Education Monitoring Report "Accountability in education. Meeting our Commitments" emphasizes the role of a safe school environment in education (Accountability in education..., 2017). Safe school environment:

- encourage behaviour where the consequences and benefits of a breach are clearly defined and understandable;

- the school environment is perceived as the frequency and quality of interaction between its staff, pupils, their parents and the entire school community; 
- a safe school balances physical security and a supportive environment, is prepared for crisis situations, offers its students pre-and-post-class activities, and promotes successful schoolcommunity collaboration. Positive behaviour is linked to the improvement of pupil performance, so both parents and educators should support positive behaviour.

School violence includes physical, psychological and sexual violence. Cybercrime has become popular. Cyberbullying includes being bullied by messages, i.e. someone sending mean instant messages, postings, emails and text messages or creating a website that makes fun of a student or by pictures, i.e. someone taking and posting online unflattering or inappropriate pictures of a student without permission; it also refers to being treated in a hurtful or nasty way by mobile phones (texts, calls, video clips) or online (email, instant messaging, social networking, chartrooms) and online hurtful behaviour (Behind the numbers..., 2019). Cyberbullying and other forms of violence have increased over the last decade, creating new concerns for educational institutions, teachers, parents and students. Available data from studies (Shariff, Churchill, 2009; Dilmaç, 2009; Catalano, 2012; Marzano, Lubkina, 2013) show that the number of young people affected by cybercrime is increasing. For young people, the web and the physical world become a whole.

Bullying is a common occurrence in the school environment. Bullying is characterised by aggressive behaviour that involves unwanted, negative actions, is repeated over time, and an imbalance of power or strength between the perpetrator or perpetrators and the victim (Behind the numbers..., 2019). A national approach to creating a safe school environment, effective monitoring and support system contributes to reducing school violence, as highlighted in the latest UNESCO publication "Behind the Numbers: Ending School Violence and Bullying". The study was published at the 2019 World Education Forum, London, urging world countries not to leave violence to teachers (Behind the numbers..., 2019).

The teacher is often the first person to observe the actions, thoughts and feelings of the adolescent. It instinctively felt his follow-up. At this point, the teacher becomes his friend. A teacher's profession is a profession of a mission. A successful teacher is the one who perceives his or her professional activities as calling, where the main essence is serving to the nation and humanity (Baltusite, Katane, 2017).

The aim of the study is to find out the views of adolescents about reducing violence in the school environment.

\section{Methodology}

The scientific research was carried out in Jurmala (Latvia) during 2018-2019. Students from Majori Secondary School took part in this investigation. 34 students - 16 boys and 18 girls (age 12-14), 12 teachers (work experience average 9.6 years) and 5 experts were invited to participate in this research.

The question of the research - what is the opinion of adolescents about the impact of the methodological material „Be positive!” in reducing violence in the school environment? The research was organized in four parts: 1-the first survey for adolescents; 2-the survey for teachers; 3-approbation of the methodological material "Be Positive!" (Ledina, 2019), 4-the second survey for adolescents.

In both surveys for adolescents the main questions were similar in order to find out the adolescents' change of opinion before and after approbation of the methodological material „Be Positive!”. A questionnaire for teachers was developed to clarify teachers' actions in dealing with student conflict situations. The research methods such as questionnaires, discussions and experiment were used in the current investigation. The data was processed using the statistical data processing program SPSS for statistical analysis. The results have been summarized and the relevant ones are presented graphically using calculations of percentage.

\section{Results and Discussion}

Adolescent violence in the school environment is mainly in the form of emotional mobbing (denigration, humiliation, cyberbullying), but physical violence is also common. Violence is most intensified by the indifference of others. Sometimes other students, teachers, parents watch the offender's actions with indifference and do not react. It strengthens the abuser's confidence in his or her immunity. It is very important for the abuser to understand the consequences of his actions and to take responsibility for 
what he has done. It is also important for the victim to face the abuser. If you cannot confront the abuser yourself, don't be silent, but seek immediately help from adults.

Everyday school environment is mostly meant to help victims of violence. It is forgotten that the abuser also needs help. In order to reduce adolescent violence in the school environment, the teacher, together with support staff, identify problems and their causes in a timely manner, and promote mutual understanding and respect.

A survey of teachers was conducted to determine the involvement of teachers in solving adolescents' personal problems and conflict situations at school.

The finding show that all teachers are $100 \%$ engaged in solving adolescent's personal problem and conflict situations at school (Figure 1). Comparatively more adolescents' personal problems are dealt with conflict situations. Results shows that $75 \%$ of teachers are 'always' and 'often' involved in personal problems, but $68 \%$ in conflict situations.

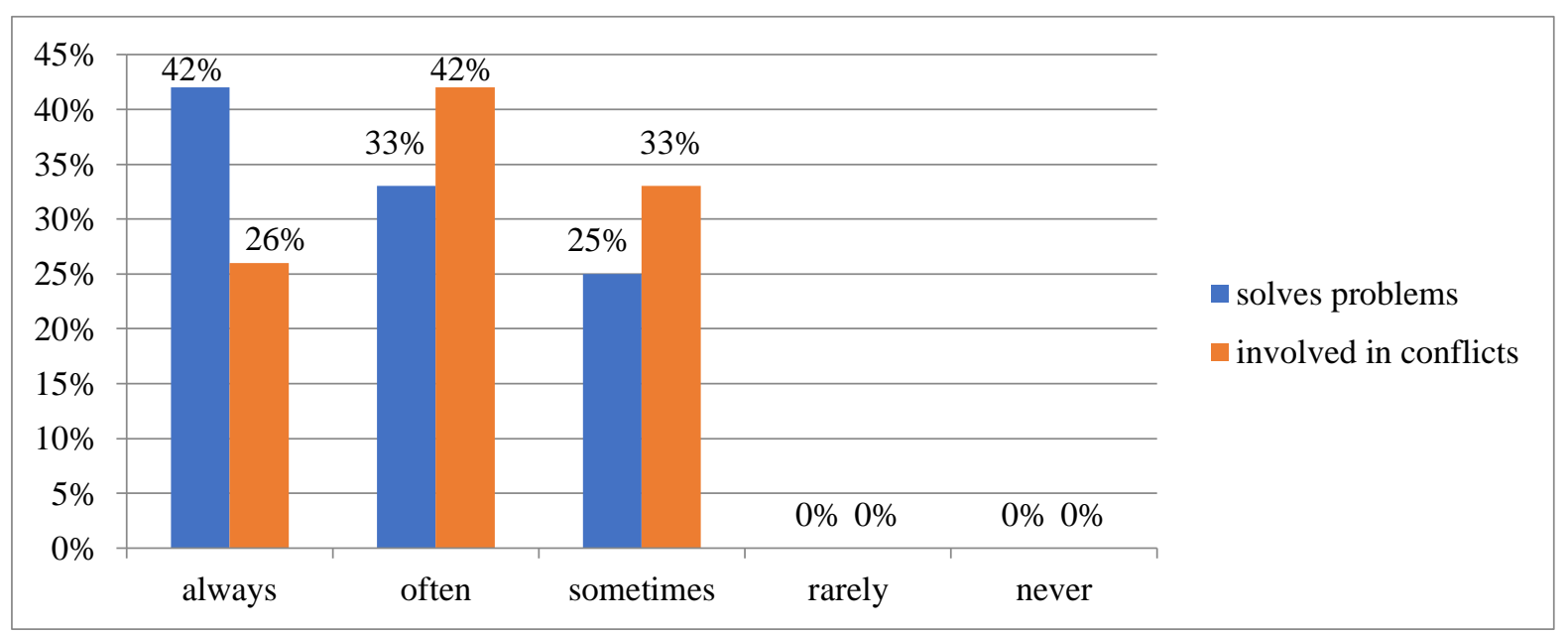

Figure 1 Teacher involvement in solving adolescents' personal problems and conflicts at school.

It is important to find out if teachers are sufficiently committed to the resources available at the school and support staff in resolving conflict situations. Data analysis shows, that all teachers are $100 \%$ committed to support staff and parents in resolving conflict at school (Figure 2). Third part of teachers involve parents ('always' $-25 \%$, 'often' $-33 \%$ ), they explain this by the parents' close contact with the school.

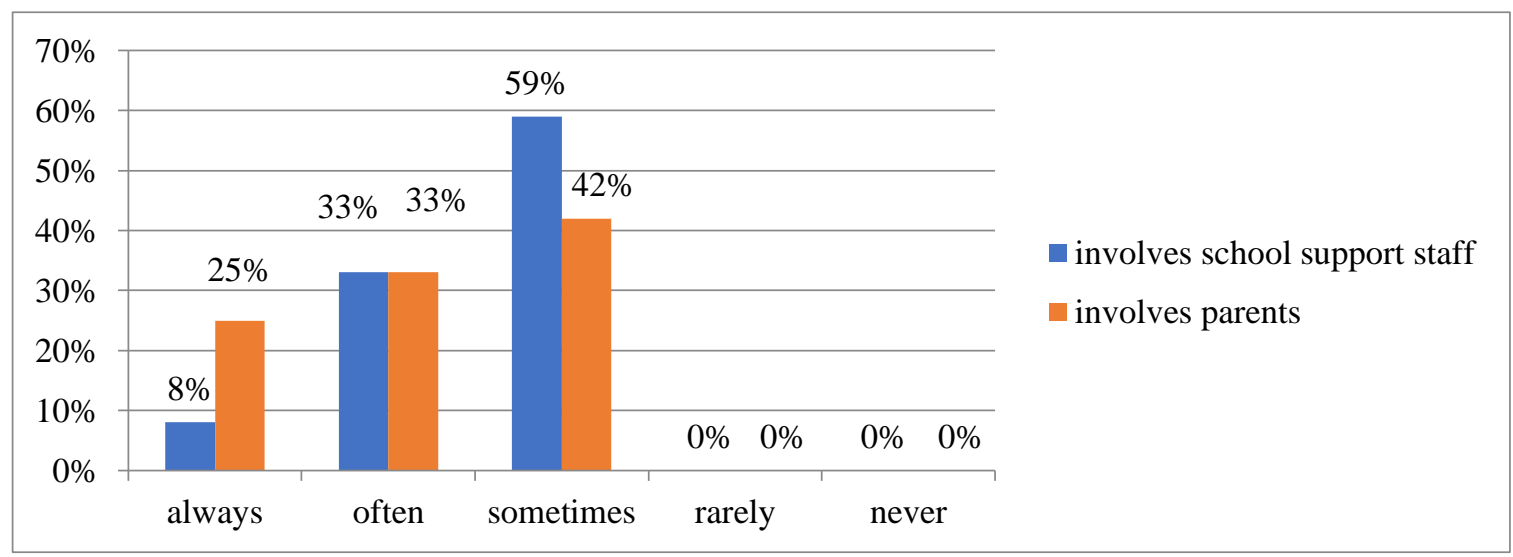

Figure 2. Involvement of support staff and parents in conflict resolution.

In the survey, adolescents indicated where they turned to for help with violence (Figure 3). The data show that in $50 \%$ of cases the victim does not seek help; they accept the crime or try to solve the problem themselves. Sufficiently enough $-26 \%$ of teenagers turn to their friends for help in cases of violence. Only $3 \%$ seek help from a class teacher. 


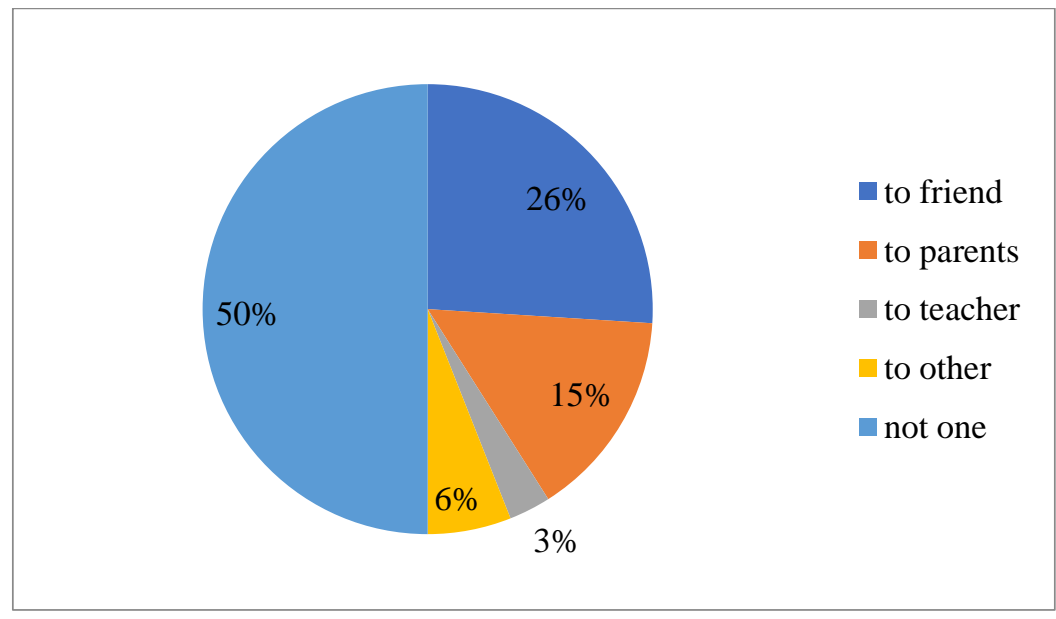

Figure 3. Adolescents seek help in cases of violence.

After collecting the data of the student survey, methodological material was developed. The aim of the methodological material "Be positive!" (Ledina, 2019) is to develop tolerance, positive behaviour in the educational institution. Using the tasks offered in the methodological material, to encourage adolescents to analyse and not consider violence as acceptable, to analyse its causes and consequences. Stimulate adolescents' awareness of each individual's responsibility.

Five experts - specialists with appropriate education and work practice with adolescents - participated in the evaluation of the methodological material. It was evaluated and supported by experts and recommended for use with adolescents.

After the pedagogical experiment, the adolescents were repeatedly surveyed (Figure 4). Adolescents in surveys indicated that they feel safe in the school and classrooms they are studying in. Comparing the respondent's answers before and after approbation of the methodological material, it can be seen that the number of respondents who 'always' feel safe in class and school has increased by 2 percentage points (before $-18 \%$, after $-20 \%$ ). The number of respondents who 'often' feel safe at school and in the classroom has increased by 15 percentage points (before $-47 \%$, after $-62 \%$ ). The number of respondents who 'sometimes' feel safe at school and in the classroom has decreased by 8 percentage points (before $-26 \%$, after $-18 \%$ ). In contrast, no respondents reported "rare" after approbation.

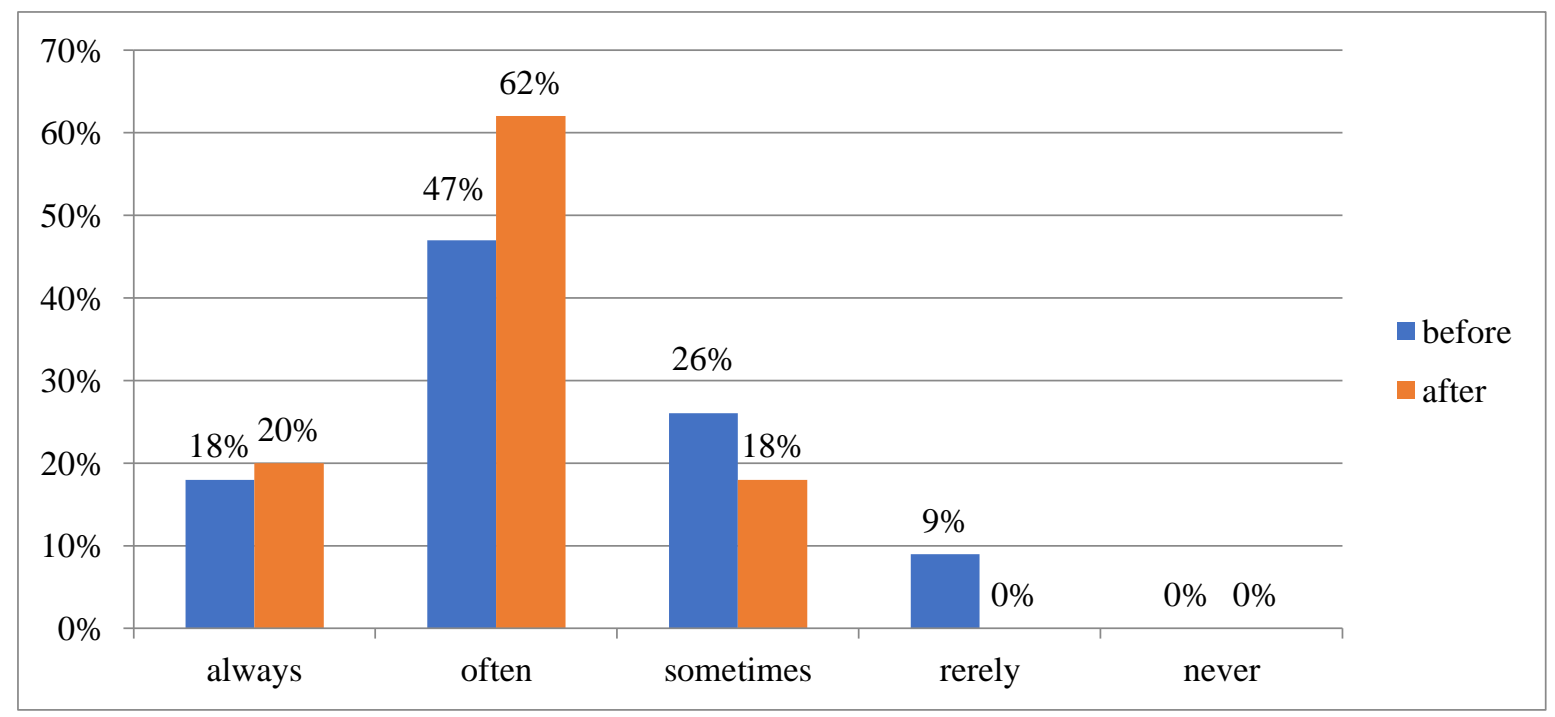

Figure 4. Adolescents' safety at school and in the classroom.

In both surveys, the adolescents indicated whether they fear any of their classmates (Figure 5). Comparing these answers before and after the methodological material "Be Positive!" approbation, it can be concluded that the fear of classmates has diminished. The indicator "often' has fallen by 15 percentage points ( $24 \%$ before, after $9 \%$ ). Respondents who tend to feel "rarely" feared by 
classmates have increased by 9 percentage points (before $38 \%$, after $47 \%$ ), they feel safe at school and in the classroom. No one pupil has indicated their fears in the indicator 'always' and 'never'.

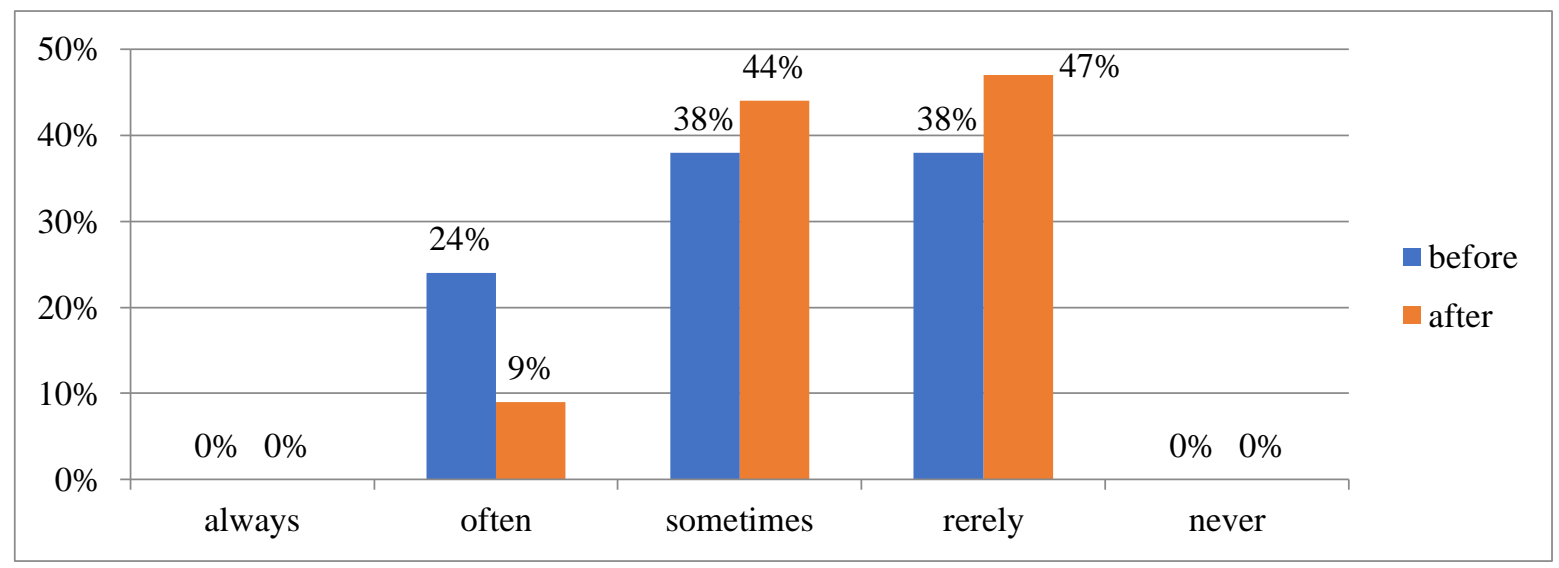

Figure 5. Adolescents' fear of classmates.

Using the methodological material 'Be positive!' adolescents' sense of security at school and in the classroom has improved, but adolescents' sense of fear from their classmates has significantly decreased.

\section{Conclusions}

- School is an environment where adolescents accumulate family relationship models in society.

- Adolescents are active users of verbal aggression. This is also largely due to the specific nature of the age group.

- Positive family relationships, parental support and understanding reduce the risk of aggressive behaviour by adolescents. Inconsistency, conflicting relationships, and lack of emotional support from parents can negatively affect adolescent behaviour.

- All teachers are $100 \%$ involved in solving adolescents' personal problems and conflict situations at school. Support staff and parents are $100 \%$ involved.

- The data show that $50 \%$ of respondents who have experienced violence do not seek for help, they accept the crime or try to solve the problem by themselves, $26 \%$ of adolescents seek help from their friends in case of violence, while only $3 \%$ seek help from a class teacher.

- Using the methodological material 'Be positive', adolescents' sense of security at school and in the classroom has improved. Adolescents' sense of fear from their classmates has significantly decreased.

- Teenagers positively evaluated the methodological material "Be Positive!". It has encouraged them, promoted self-education, knowledge, skills and attitudes, stimulated active learning.

\section{Bibliography}

1. Accountability in education: meeting our commitments. Global Education Monitoring Report, 2017/8. (2017). Global Education Monitoring Report Team. France: UNESCO. Retrieved from https://unesdoc.unesco.org/ark:/48223/pf0000259338

2. Baltusite R., Katane I. (2017). The Modern Teacher's Career. In V. Dislere (Ed.), The Proceedings of the International Scientific Conference Rural Environment. Education. Personality (REEP), 10. Jelgava: LLU, 30-39. Retrieved from https://lufb.llu.lv/conference/REEP/2017/Latvia-UnivAgricult-REEP-2017_proceedings-30-39.pdf

3. Behind the numbers: ending school violence and bullying. (2019). France: UNESCO. Retrieved from https://unesdoc.unesco.org/ark:/48223/pf0000366483

4. Catalano S. (2012). Stalking Victims in the United States. Revised. U.S. Department of Justice. Office of Justice Programs Bureau of Justice Statistics. Retrieved from https://www.bjs.gov/content/pub/pdf/svus_rev.pdf 
5. Cobb N.J. (2010). Adolescence: Continuity, Change and Diversity ( $7^{\text {th }}$ ed.). Retrieved from http://cobb.sinauer.com/chapter06.html

6. Correll J.R., Walker S.C., Edwards T.C. (2017). Parent Perceptions of Participating in a Program for Adolescents Who Are Violent at Home. Journal of Family Violence, 32(5), 243-255. doi: 10.1007/s10896-016-9847-6

7. Dilmaç B. (2009). Psychological Needs as a Predictor of Cyber Bullying: A Preliminary Report on College Students. Educational Sciences: Theory and Practice, 9(3), 1307- 1325. Retrieved from https://files.eric.ed.gov/fulltext/EJ858926.pdf

8. Knoff H.M. (2003). The Assessment of Child and Adolescent Personality. London: The Guilford Press.

9. Ledina I. (2019). Pusaudžu vardarbīga uzvedība skolas vides kontekstā [Reducing Teenage Violence in the School Environment]. Master Thesis. Jelgava, Latvia: Latvia University of Life Sciences and Technologies. (in Latvian)

10. Marchenkova M. (2017). Tolerance as an exhibition of humanism for the rising generation. In V. Lubkina, A. Zvaigzne (Eds.), the Proceeding of the International Scientific Conference Society. Integration. Education, 2. Rezekne: RTA, 132-141. doi: 10.17770/sie2017vol2.2320

11. Marzano G., Lubkina V. (2013). Cyberbulling and real reality. In the Proceeding of the International Scientific Conference Society. Integration. Education, 2. Rezekne: RTA, 412-422. doi: 10.17770/sie2013vol2.598

12. Medne D. (2010). Socio-structural relevant trends of a family in transformative society. In Proceedings of ATEE Spring University conference Teachers of 21 st century: Quality education far quality Teaching. Riga: LU, 35-47.

13. Mendes D.D., Mello M.F., Ventura P., De Medeiros Passarela C., De Jesus Mari J. (2008). A systematic review on the effectiveness of cognitive behavioral therapy for posttraumatic stress disorder. International Journal of Psychiatry in Medicine, 38(3), 241-259. doi: 10.2190/PM.38.3.b

14. Poudžiunas I. (2011). Dusmas un agresija vardarbību pārcietušajiem jauniešiem un dusmu pārvaldīšanas programmas efektivitāte [Anger and aggression in adolescent abuse survivors and effectiveness of anger management programs]. Doctoral Thesis. Riga: University of Latvia. Retrieved from https://dspace.lu.lv/dspace/bitstream/handle/7/4672/20585-Inta_Poudziunas_2011.pdf (in Latvian)

15. Shariff Sh., Churchill A.H. (2009). Truths and Myths of Cyber-bullying: International Perspectives on Stakeholder Responsibility and Children's Safety. New York: Peter Lang Publishing Inc.

16. Simane-Vigante L., Plotka I., Blumenau N. (2018). Research of the Relationship of Criminal Violence, Adult Attachment Styles and Personality Traits of Violent Male Offenders. In V. Dislere (Ed.), The Proceedings of the International Scientific Conference Rural Environment, Education, Personality (REEP), 11. Jelgava: Latvia University of Life Sciences and Technologies, 128-141. doi: 10.22616/REEP.2018.015

17. World report on violence and health: summary. (2002). Geneva: World Health Organization, 54. Retrieved from https://www.who.int/violence_injury_prevention/violence/world_report/en/summary_en.pdf 